Ivanková V., Belovičová M.

\title{
Clostridial infections in the world and in Slovakia in the patient safety context
}

\author{
St. Elizabeth University of Health and Social Sciences, Bratislava, Slovakia
}

vierkai@centrum.sk,mriab9@gmail.com

\author{
Іванкова В., Беловічкова М. \\ Клостридіальні інфекції в світі та в Словаччині \\ в контексті безпеки паціснтів \\ Вища школа охорони здоров'я та соціальної роботи \\ Св. Алжбети, м. Братислава, Словаччина
}

\author{
Иванкова В., Беловичкова М. \\ Клостридиальные инфекции в мире и в Словакии \\ в контексте безопасности пациентов \\ Высшая школа здравоохранения и социальной работы \\ Св. Елизаветы, г. Братислава, Словакия
}

\section{Introduction}

Infection with Gram-positive sporulating bacteria Clostridium difficile (CDI) is currently a serious health problem worldwide due to its increasing incidence and mortality. In hospitalized patients, it is the most common cause of diarrheal disease, and healthcare professionals face many challenges related to its identification, treatment, and prevention of its transmission. Evidence-based risk reduction strategies are essential to ensure a safer environment of healthcare facilities in the event of a suspected or confirmed CDI. These strategies include components for the prevention of standard infections and contact measures, care for the environment and prudent use of antibiotics.

The rise in incidence of CDI is connected with an increase in financial costs which for the European Union make $€ 3000$ million per year, and this number is expected to double over the next three decades [1]. The onset of the disease is most often associated with (over) using of broad-spectrum antibiotics and older age ( $>65$ years). In the majority of the lay population, this issue remains relatively unknown. The clinical signs of CDI are very wide - from asymptomatic colonization, through mild and transient diarrheal diseases to life-threatening pseudomembranous colitis, toxic megacolon, intestinal perforation and septic shock leading to patient death [2].

Providing safe and quality patient care is extremely important for nurses, as they are in a key position in improving the quality of healthcare through interventions and strategies in the area of patients' safety. In an effort to reduce the rate of healthcare-associated infections, it is currently recognized as a measure of hospital quality. Practice shows that while the same prevention interventions may be successful in one hospital, they may fail or be less successful in another. We assume that organizational factors, the involvement of nurses in the implementation of prevention procedures and the perception of patient safety by nurses are the main reasons of that.

\section{Core}

The incidence of CDI is increasing worldwide. In 2001, this incidence increased to 50 cases per 100,000 inhabitants and in 2005 to 84 cases per 100,000 inhabitants (ie a threefold increase compared to the incidence in 1996). In England, in 1991, CDI was identified as the primary cause of death in 499 patients, and in 2006 in 3,393 patients caused by ribotypes shortly thereafter in the Netherlands. The occurrence and rapid spread of this epidemic strain was related to its resistance to a frequently used group of antibiotics, the newly developed fluoroquinolones (levofloxacin, moxifloxacin) [3].

The incidence in Europe is 41 cases per 100,000 hospitalized patients. The most common epidemic ribotypes are ribotypes 01, 002, 014 and 078. A 2008 study, covering 34 European countries, reported that ribotype 027 occurred in only $5 \%$ of all cases. The global problem of the increasing appearance of CDI also applies to Slovakia. The Public Health Office of the Slovak Republic gives the estimated number of Clostridium difficile (CD) colonized patients in Slovakia of $7-11 \%$ in hospitalized patients, $5-7 \%$ in patients in social-care facilities and approximately of $2 \%$ in outpatients [4].

The European Center for Disease Prevention and Control (ECDC) organized a Europe-wide point prevalence survey of healthcare-associated infections in 2012, showing that $48 \%$ of gastrointestinal infections in hospitals were caused by $\mathrm{C}$. difficile and $7.7 \%$ of all health care CDI-related infections were caused by nosocomial transmission. C. difficile was on the eighth place in the list of pathogens causing nosocomial infections. Data from Germany have shown that the incidence of CDI in hospitals is 2-4 times higher than nosocomial infections caused by MRSA [5].

Since 2013, Clostridium difficile belongs to one of the five most common pathogens of nosocomial infections in Slovakia. In 2017 , with $17.3 \%$ it became the most common originator and the cause of all nosocomial infections. In 2017, in Slovakia, most nosocomial CDI cases $(88.5 \%)$ were reported from internal medicine departments, $7.4 \%$ of cases of CDI-NN occurred in surgical departments, $2.8 \%$ in anaesthesiology and resuscitation departments and $1.1 \%$ in pediatric departments. The age distribution of reported CDI cases in Slovakia in 2010-2017 shows that the risk of infection increases with age, with the elderly representing the largest risk group, followed by young children. The incidence of patients aged 65 and over was 9.8 per 10,000 inhabitants in Slovakia. The incidence in 
children under 1 year of age was 2.6 per 10,000 inhabitants in Slovakia. The average age of CDI patients during the study period was 68.6 years [6]. The following table shows the incidence of nosocomial infections caused by CDI in 2019 in the hospitals of the WORLD HEALTH network presented by the main epidemiologist in the World of Health and ProCare network.

Table. Incidence of Clostridial infections in hospitals of the World Health network (Skálová, 2019)

\begin{tabular}{|l|c|c|c|}
\hline \multicolumn{1}{|c|}{ Hospitals WH } & $\begin{array}{c}\text { Incidence of NN - Clostridial infections in 1-10.2019 } \\
\text { of which number } \\
\text { Number of reported NN }\end{array}$ & $\begin{array}{c}\text { Incidence of patients } \\
\text { with CDI, \% }\end{array}$ \\
\hline Košice “Železničné zdrav" & 28 & 1 & 3,57 \\
\hline Rožňava & 199 & 15 & 7,54 \\
\hline Vranov n/T & 152 & 15 & 9,87 \\
\hline Partizánske & 132 & 9 & 6,82 \\
\hline Svidník & 149 & 8 & 5,37 \\
\hline Trebišov & 194 & 5 & 2,58 \\
\hline Michalovce & 250 & 40 & 16,00 \\
\hline D. Streda & 269 & 47 & 17,47 \\
\hline SNV & 234 & 19 & 8,12 \\
\hline Rimavská Sobota & 162 & 12 & 7,41 \\
\hline B. Štiavnica & 32 & 8 & 25,00 \\
\hline Žiar n/Hronom & 117 & 42 & 35,90 \\
\hline Humenné & 127 & 24 & 18,90 \\
\hline Topol'̌any & 220 & 17 & 7,37 \\
\hline Galanta & 222 & 23 & 10,36 \\
\hline SPOLU & 2487 & 285 & 11,46 \\
\hline
\end{tabular}

\section{Clostridial infections}

Clostridium difficile is a gram-positive bacterium that was first isolated from the stool of healthy newborns in 1935 by Hall O'Tolle. The bacterium was originally named Bacillus difficilis, which was supposed to express problems and difficulties in its isolation [5].

In 1978, CDI was identified as the cause of antibioticrelated colitis. This bacterium is commonly found in nature and in wastewater and surface water. Another, still unconfirmed, source of bacteria in the community is probably pets and particular meat products [7].

The virulence of $\mathrm{C}$. difficile is given by its ability to form resistant spores and produce toxins. The spores are acidresistant, they are able to survive transport through the stomach into the small intestine, where they germinate and the vegetative cells produce toxins [8]. In its spores, the bacterium can survive harsh environments and conventional sterilization techniques. CDI spores are resistant to high temperatures, ultraviolet radiation, strong chemicals and antibiotics. Spores are resistant to antibiotics, they can remain in the gastrointestinal tract and potentially contribute to recurrent diseases after treatment and eradication of vegetative CDI.

Currently, three toxins are known: toxin $\mathrm{A}$ - enterotoxin damaging intestinal epithelial cells and reducing the efficiency of the immune system, toxin B - cytotoxin causing necrosis and ulceration of affected tissues and the formation of pathognomonic patches, the third is the so-called binary toxin, the effects of which are currently not fully known [3]. The production of both, A and B toxins is a major determinant of
CDI virulence, i.e. C.difficile strains that do not produce toxins do not cause disease (are not pathogenic) [9].

\section{Risk factors}

The main risk of acquiring CDI is present within four weeks after antibiotic treatment, representing $40 \%$ to $60 \%$ of cases [10]. Other risk factors are age (over 65 years), comorbidities, hospitalization in the last three months and stay in a facility for the long-term sick or in a nursing home [11]. Treatment with proton pump inhibitors also increases the risk of CDI, but enteral nutrition does not play a significant role. Possible risk groups include patients with weakened immunity or immunodeficiency and patients with chronic inflammatory bowel disease [12].

\section{Clinical condition}

CDI infection occurs by the fecal-oral route due to ingestion of spores that are resistant to the environment. During the gastrointestinal transition, bile acids and other substances stimulate the germination of vegetative growth forms, these produce toxins depending on the surrounding microflora (microbiota) [13]. Typical manifestations of CDI are abdominal cramping, extensive diarrhea (mucoid, greenish, foul-smelling, and watery stools) corresponding to type V-VII in the Bristol scale of stool types, fever and leukocytosis, which may occur several days after the start of antibiotic treatment or up to 8-10 weeks after its end. If the stools are not large and bulky, in immobile patients, this condition can be mistaken for sudden stool incontinence. The main symptoms of colitis 
include diarrhoea, ileus and toxic megacolon [7]. Ileus is a disruption of intestinal patency. Toxic megacolon is characterized by enlargement of the intestine along with a significant elevation of inflammatory parameters. Severe course may be accompanied by other symptoms: fever, signs of shock and peritonitis, leucocytosis $>15,000$, shift of blood count to the left, increased creatinine and others [8]. The feared complication is recurrences, which may occur several days after the end of diarrhoea, usually occurring within 2 months after the previous attack. They may have an easier or more difficult course. After the first attack, the probability of recurrence is in the range of $15-25 \%$. If a second CDI attack has occurred, the probability of further recurrence is $40-50 \%$. They are not caused by antibiotic resistance, but by re-infection caused by spores from the patient's surroundings. A patient with recurrent attacks of Clostridial colitis is at risk of disruption of the internal environment, dehydration and overall mental and physical exhaustion of the body. Frequent recurrences are the second leading cause of death from Clostridial infection [4]

\section{Diagnostics}

Diagnosis requires detection of $\mathrm{C}$. difficile toxines or C. difficile producing toxins in a diarrhea stool sample. Diagnostic tests can be divided into tests for C. difficile product detection (eg Glutamate dehydrogenase, volatile fatty acids, toxins), tests for the detection of CDI genes (16S rRNA, toxin genes) and cultivation methods for the isolation of toxinproducing bacteria [14].

\section{Treatment}

Evidence of toxigenic CDI requires prompt treatment adjusted to the possible risk. This usually leads to clinical improvement within 48 to 72 hours. If possible, antibiotic treatment that has resulted in toxigenic CDI should be interrupted or changed to a less colitogenic drug, such as tetracycline or tigecycline. Continued systemic antibiotic treatment increases the likelihood of recurrence. Naturally, adequate rehydration therapy should also be given. Motility inhibitors should be avoided and treatment with proton pump inhibitors should be discontinued if possible [12]. Oral metronidazole is a first-line drug for simple CDIs, but should not be used for severe CDIs. This is because in such cases the response to treatment is weaker $(73 \%$ vs. $81 \%)$. In the initial treatment of severe CDI, oral vancomycin is a first-line drug; alternatively, oral fidaxomycin may be used [15]. Colonoscopic stool transmission (stool transplantation) may be recommended based on better acceptance and prevention of bacterial contamination of the small intestine by faecal microbes, in addition to its higher success rate. Within two weeks after stool transplantation, a highly diverse protective donor flora develops, predominantly of the natural Bacteroides species [16].

\section{Prevention of the onset and spread of infection}

Two types of measures are essential: isolating infected patients and disinfecting the environment in which they are housed. Patients should be isolated in separate rooms with their own toilet, in case of infection of several patients it is possible to place them in one room. It is advisable to set aside caregivers who use protective equipment to protect them from C. difficile infection before entering the room. The most important thing is the consistent use of disposable gloves and hand washing according to the valid recommendations. It is not advisable to use alcoholic solutions for hand washing, as they may lead to the germination of $\mathrm{C}$. difficile spores. The patient should be treated in an isolation regimen for the entire duration of diarrhoea. After discharge of the patient (s) with CDI, thorough mechanical cleaning and disinfection of all surfaces and objects in the patient's room with sporocides must be performed [4].

\section{Patient safety}

The definition of patient safety emerged from the healthcare quality movement and is defined as "prevention of patient harm" [17]. Emphasis is placed on a care delivery system that prevents mistakes, learns from mistakes that may occur and is built on a safety culture that involves healthcare professionals, organizations and patients. Safety is the foundation on which all aspects of quality of care are being built [18]. Recently, attention has focused on understanding the common attitudes, beliefs, values and assumptions that underpin people's safety activities and the potential importance of these common characteristics in initiating lasting changes in patient safety. In the literature, these common characteristics are often referred to as an organization's "safety culture" [19].

The pursuit of these goals are the common beliefs and values of the organization that set them apart from the others. It is generally accepted that it is a learned entity. The proposals range from a very simple: "the way we do things here" to highly complex ones, involving common basic assumptions, external adaptation and internal integration. Organizational culture includes not only what the members of the organization have learned, but also what they believe in. Includes perceptions and practices shared within the organization and not just on the basis of the values held by individual members. This model of shared beliefs and values makes sense to members of the organization and provides them with rules of conduct in their organization. Organizational culture and behaviour can therefore be seen as a model system of perceptions, meanings and beliefs that facilitates and guides individual behaviour at work [20].

CDI prevention procedures related to patient safety Patient safety procedures are defined as "procedures that reduce the risk of adverse events related to the exposure to medical care throughout the range of diagnoses or conditions". This definition is specific but relatively incomplete, as several practices have not been researched properly for respect of their effectiveness in preventing or mitigating damage. In the past, we have often observed the responsibility of nurses for patient safety in the narrow aspects of patient care, such as the prevention of treatment errors and the prevention of patient falls. Although these dimensions of safety remain important in the nursing field, the breadth and depth of patient safety and quality improvement are much greater. Error analyses relate to "non-compliance with standard operating procedures, poor leadership, errors in communication or teamwork, overlooking 
or ignoring individual vulnerabilities, and losing track of objectives" [21].

CDI prevention measures include patient placement, use of personal protective equipment (gloves, coats, masks, and eye protection), hand hygiene, decontamination, and appropriate laundry and waste material handling. Isolation involves the physical separation of patients with infections (or suspected of infections) to interrupt the transmission of potential pathogens between other patients, staff and visitors, and it has historically been used to control for preventing and spreading of the infectious diseases [22].

The marking of the patient's room is a reminder to the medical staff about the necessary procedures for an isolation. Although there is much discussion about the effectiveness of isolation measures, the practice is based on reliable theoretical justification and is generally accepted. Nurses and all healthcare professionals must follow strict protocols without compromising patient safety. Isolation or other forms of restraint affect the wellbeing and freedom of patients and prescribed environments and isolation procedures bring barriers to physical, sensory and psychosocial needs of patients [23], which, in our view, also places an invisible burden on staff.

\section{Adherence to organizational principles}

Effective organizational rules in a medical facility require compliance with organizational rules and procedures on the part of its employees. However, this is far from being universal. The degree of suboptimal compliance is still reported in basic procedures such as hand hygiene and antibiotic prophylaxis in surgery. A conceptual seminar survey conducted by Cabana et al. found that nurses' compliance with the guidelines could be hampered by a number of obstacles, such as: lack of knowledge, lack of familiarity and lack of self-commitment and efficiency in implementing good practices [24].

\section{Adherence to prevention procedures and workload}

The vigilance of bedside nurses is essential for their ability to ensure patient safety. It is therefore logical that with the growing number of patients, the ability of nurses to provide safe care will eventually be compromised. Several studies have shown an association between the number of nurses and patient safety, documenting an increased risk of patient safety events, morbidity, and even mortality with increasing numbers of patients per nurse. The nurse-patient ratio is only one aspect of the relationship between workload and patient safety. The overall burden on nursing is also likely to be related to increased patient turnover [25], which in our opinion is also associated with an increased risk of non-compliance with CDI transmission prevention procedures, even though the total number of nurses is considered to be adequate.

Influence of management on compliance with prevention procedures

Strong leadership has always been considered essential for successful campaigns for control and prevention of infections. Some authors confirm that hospitals with more effective management have demonstrated better hand hygiene and better managed procedures of dressing and using gloves among staff. They are also less likely to report obstacles to implementing control and prevention of communicable diseases. Effective leadership styles can also have a very positive effect on prevention outcomes, while too strong topdown control can have a negative effect on nurses' job satisfaction and their ability to respond appropriately [26].

The impact of job satisfaction on adherence to prevention procedures

There are very few studies that have somehow identified the relationship that exists between positive job satisfaction and adherence to infection prevention practices. However, a consistent relationship between low levels of employee satisfaction and adverse outcomes such as increased transmission of infections, mortality, has been demonstrated, even though the mechanisms and the direction of causation remains unclear [27].

\section{Culture of communication}

Unless there is a proper culture of communication in the organization with staff, patients and nurses, they will not have sufficient knowledge of the risks of infection and of the care needed to prevent CDI. In addition, without multiorganizational communication, it will be difficult to gain a proper understanding of effective patient safety strategies in hospitals that show high levels of performance [28].

\section{Impact of training on adherence to procedures}

In addition to dissemination of information, the aim of the training should be to persuade participants to believe in their ability to achieve the desired change through their behaviour. Self-efficacy theory identifies four ways to influence the change of behaviour. These include: performance regulations that focus on changing beliefs about a person's ability to perform desired behaviour, continuing education that modifies self-efficacy by observing others, verbal persuasion that modifies behaviour through significant interaction with others, and emotional strain that supports the idea that more relaxed, less stressed participants would rather follow the prescribed procedures and perform proper hand hygiene. Behavioural change forces individuals to move away from their comfort zone, so it is often undesirable. It should therefore come as no surprise to find varying degrees of non-compliance with a change in behaviour. If individuals do not perceive the new behaviour as rewarding enough to accept it, all kinds of resistance will be observed. The main cause of active resistance are the extensive difficulties with the integration of habits that result from previous clinical training and daily work routine. Saint et al. ascribes insufficient adherence to control and prevention procedures to either "active defendants" or "organizational advocates". Active resistance is described as a lack of full confidence of competent authorities about their commitment to new procedures. On the other hand, organizational criminals are defined as individuals who are generally executive managers at a medium to high level and who hinder or postpone certain activities without overt and public expression of active resistance. These (professional) individuals resist the change by increasing the effort required to implement evidence-based practices [29]. 
Monitoring procedures in the context of patient safety

In the last decade, there has been an increasing pressure to increase the use of quality indicators and health care measures, in particular infection rates. Rates for healthcare associated infections have been designed as an effective indicator of hospital system failure and have been used as indicators of professionalism of the staff, of the training, of organizational stress, management failure, inadequate systems, reliability and of the resilience. They provide a space to identify organizations whose organizational culture has a more comprehensive approach that fully integrates control and prevention of the infection into the hospital management and the quality agenda [30].

\section{Conclusions}

It is necessary to build on the efforts of research on risk perception from other disciplines to understand how nurses think and decide about the CDI problem. This can help us to inform on the development of effective management and communication strategies in order to maximize the quality of the care provided. Managing the diarrhoea and taking preventive measures to control the infection are the most unfavourable aspects of treating patients with CDI. Preventive measures include contact isolation, hand hygiene, and reorganization/coordination of nursing care and the wards. Preventive measures are time consuming and significantly increase the workload of nurses in combination with the care of patients with uncontrollable frequent diarrhea attacks, which may affect their perception of patient safety and ability to concentrate their efforts to adhere to the procedures.

The incidence of CDI is rising and is beginning to affect a population that was previously considered low-risk. Nurses need to integrate CDI knowledge and skills into their practice to combat the international epidemic of multidrug-resistant organisms, as they play a crucial role in patient safety due to their constant presence at the patient's bedside. They make up the largest group of hospital staff and are familiar with the patient's everyday clinical condition, so they can effectively engage and help reduce Clostridium difficile infection (CDI) in hospitals

We can find many positive reasons to create and maintain a safe environment. One of the most important is that we do this to protect our patients. As Menšík et al. [31] propose, nurses are in the best position to improve the quality and safety of patient care. Quality professional and especially safe nursing care requires the nurses to be able to identify and solve obvious and hidden problems of the nursing practice.

\section{References}

1. Kuiper, EJ., Coignard, B., Tull, P. 2006. The onset of Clostridium difficile-related disease in North America and Europe. Clin Microbiol Infect 12 [Suppl 6]: 2-18.

2. Bátovský, M. 2012. Clostridium difficile - a growing threat? Gastroenterology and hepatology. 2012, vol. 66, no. 6, p. 438-443. ISSN: 1804-7874; 1804-803X (electronic version). [on-line] - [cit.2020-01-04]. Available online : http://www.csgh.info/dwnld/gh_2012_6_438_443.pdf.

3. Kelly, CP, Lamont, JT. 2008. Clostridium difficile - more difficult than ever. N Engl J Med. 2008 Oct 30; 359(18):1932-40.

4. Jarčuška, P., Bátovský, M., Drgoňa, L., Lišková, A., Holečková, K. 2015. Recommended procedure for the diagnosis and treatment of colitis caused by Clostridium difficile. In Modified 2nd version from August 2014 - version 2.0 Via practica Suplement 1. 2015; 12(S1) ISSN 1336-930X ročník XII. [on-line] - [cit.2020-01-10]. Available online: www.solen.sk.

5. ECDC. Clostridium difficile infection. Basic fact. 2013. Stockholm: European Center for Disease Prevention and Control; 2013 [on-line] - [cit.2020-01-04]. Available online: http //www.ecdc.europa.eu/en/en/healthtopics/healthcareassociated_infections/clostridium_difficile_infection/pages/basic_facts.aspx.

6. Novák, M. Mazáková, I. Červeňová, T., Hudečková, H. 2019. Incidence and the issue of infections caused by clostridium difficile in Slovakia. Medical magazine "Zdravotnícke listy", Volume 7, Number 1, 2019 ISSN 1339-3022 p. A22.

7. Beneš, J., Husa, P., Nyč, O. 2012 Recommended procedure for diagnosis and treatment of colitis caused by Clostridium difficile. Prague: ČLS JEP; 2012 [on-line] - [cit.2020-01-15]. Available online: http://www.infekce.cz/ dokument1.htm\#Standardy.

8. Škapová, T. 2014. Currently on the issue of Clostridium difficile. Newsletter of CKL ZÚ 7(2):5-6. [on-line] [cit.2020-01-04]. Available online: http://www.zuova.cz/Content/files/zpravodaj_ckl/zpravodajckl201102.pdf.

9. Warny, M, Pepin, J., Fang, A, Killgore, G., Thompson, A., Brazier, J. et al. 2005.Toxin production by an emerging strain of Clostridium difficile associated with outbreaks of severe disease in North America and Europe. Lancet. 2005 Sep 2430;366(9491):1079-84.

10. Bauer, MP, Notermans, DW, Van Benthem, BH, et al. 2011. Clostridium difficile infection in Europe: hospital survey. Lancet. 2011; 377: 63-73.

11. Grunewald, T., Kist, M., Mutters M., Ruf, BR., Kern, WV. 2010. Clostridium-difficile infection [Clostridium difficile infection] Dtsch Med Wochenschr. 2010; 135: 699-703.

12. Lübbert C, Johann C, Kekulé AS, et al. 2013. Behandlung als Risikofaktor für das Auftreten einer Clostridium difficile-Infektion (CDI). Gastroenterol. 2013; $51:$ 1251-1258.

13. Heeg, D., Burns, DA., Cartman, ST., Minton, NP. 2012. Spores of clinical isolates of Clostridium difficile show a different germinate response to bile salts. In PLoS One. 2012; 7. 
14. Delmee, M. 2011. Laboratory diagnostics of Clostridium difficile. Clin Microbiol Infect. 2001; 7: 411-416.

15. Bartsch, SM., Curry, SR., Harrison, LH., Lee, BY. 2012. The potential economic value of screening hospitalizations for Clostridium difficile. Eur J Clin Microbiol Infect Dis. 2012; 31: 3163-3171.

16. Khoruts, A., Dicksved, J., Jansson, J., Sadowsky, MJ. 2010. Changes in the composition of human faecal microbiome after bacteriotherapy in the case of recurrent diarrhea associated with Clostridium difficile. J Clin Gastroenterol. 2010; 44: 354-360.

17. Clancy, CM., Farquhar, MB, Sharp, BA. 2005 Patient safety in nursing practice. J Nurs Care Qual. 2005 Jul - Sep; 20 (3): 193-7.

18. Mitchell, H. P., et. al., 2008. Defining Patient Safety and Quality Care. Huges, R. G. / ed. Patient Safety and Quality: In Evidence-Based Handbook for Nurses [online] Rockville: AHRQ, No.: 08-0043 IDNBK2651, p. 1-5. [on-line] [cit.2020-01-12]. Available online: http://www.ncbi.nlm.nih.gov/books/NBK2651.

19. Dodds, A, Kodate, N. 2011. Accountability, Organizational Learning and Risks to Patient Safety in England: Conflict or Compromise. Health Risk Soc. 2011; 13: 327-346. doi: 10.1080 / 13698575.2011 .575454$.

20. Hofstede, G, Hofstede, GJ and Minkov, M.. 2010. Culture and Organization: Mind Programs. McGraw-Hill, New York; 2010.

21. Tourangeau, AE, Cranley- LA, Jeffs, L. 2006. The impact of nursing on hospital mortality: targeted review and related policy implications. Quality safe health care. 2006. February; 15 (1): 4-8.

22. Masterton, RG, Mifsud, AJ, Rao, GG. 2003. Review of measures for hospital isolation and infection control. J Hosp Infect. 2003; 54 (3): 171-3.

23. Gammon, J., Hunt, J., Williams, S. et al. 2019. Infection prevention control and patient safety organizational culture in isolation context: study protocol. BMC Health Serv Res. 19, 296 (2019) doi: 10.1186 / s12913-019-4126-X

24. Cabana, MD, Rand, CS, Powe, NRP et al. 1999. Why do doctors not follow the guidelines for clinical practice? Framework for improvement. JAMA. 1999; 282: 1458-1465.

25. Aikern, LH, Sermeus, W, Van Den Heede, K. et al. 2012. Safe person, satisfaction and quality of hospital treatment: cross-sectional surveys of nurses and patients in 12 European countries. BMJ. March 20, 2012 ; 344 : e1717. Epub 2012 March 20.

26. Saint, S., Kowalski, CP, Banaszak-Holl, J., Forman, J., Damschroder, L. and Kerin, SL. 2010. The importance of leadership in the prevention of healthcare-associated infections: the results of a multilateral qualitative study. Infect Control Hosp Epidemiol. 2010; 31: 901-907.

27. Aiken, LH, Clarke, SP, Cheung, RB, Sloane, DM and Silber, JH 2003. Educational levels of nurses and mortality of surgical patients. JAMA. 2003; 290: 1617-1623.

28. Plsek, PE.1997. Cooperation across organizational boundaries to improve the quality of care. Am J Infect Control. 1997; 25: 85-95.

29. Saint, S., Kowalski, CP, Banaszak-Holl, J., Forman, J., Damschroder, L. and Kerin, SL. 2009. As active resistors and organizers, they act on healthcare acquired to prevent infections. Joint Committee J Qual Imag. 2009; 35: $239-246$.

30. Sevdalis, N., Undre, S., Henry, J. et ak. 2009. Development, initial reliability and validation of the observation tool for assessing nurses' technical skills in operating theaters. J Nurs Stud. 2009; 46: 1187-1193.

31. Mensik, J. S., et al., 2011. Development of a professional nursing framework: the journey toward nursing excellence. Nurs Adm. 41(6),259-64. doi: 10.1097/NNA.0b013e31821c460a.

Дата надходження рукопису до редакції: 03.03.20220 р.

The analysis of the scientific literature found that Infection with Gram-positive sporulating bacteria Clostridium difficile (CDI) is currently a serious health problem worldwide due to its increasing incidence and mortality and it is the most common cause of diarrhea in hospitalized patients. In this work we analyze preventive measures, which include contact isolation, hand hygiene and reorganization/coordination of nursing care and of the ward. Preventive measures are time-consuming and significantly increase the workload, which can affect the perception of the patient's safety level by nurses and the ability to concentrate their efforts to adhere to good practices for preventing the transmission of the infection. We also emphasize the crucial role of nurses in increasing patient safety due to their constant presence at patient's bedside. Knowing the patient's everyday clinical condition, nurses can effectively engage and help reduce Clostridium difficile (CDI) infection in the hospital.

Key words: clostridial infections, patient safety, patient isolation, preventive actions, the role of nurses in prevention.

За результатами аналізу наукової літератури встановлено, що клостридіальні інфекції (CDI) в даний час $є$ серйозною проблемою охорони здоров'я в усьому світі через зростання захворюваності і смертності, і в той же час вони стають найпоширенішою причиною виникнення діарейних захворювань у госпіталізованих пацієнтів. У міру зростання захворюваності збільшуються фінансові витрати на охорону здоров’я.

У цій роботі ми аналізуємо профілактичні заходи, які включають ізоляцію контактів, гігієну рук і організацію/ координацію сестринського догляду та відділень. Профілактичні заходи займають багато часу і значно збільшують 
робоче навантаження, що може вплинути на сприйняття медсестрами безпеки пацієнтів і їх здатність концентрувати свої зусилля на дотриманні правильних рекомендацій щодо запобігання передачі інфекції. Ми також наголошуємо вирішальну роль медсестер в підвищенні безпеки пацієнтів через їх постійну присутність біля ліжка хворого. Медсестри знайомі з щоденним клінічним станом пацієнта, тому вони можуть бути ефективно залучені і допомогти в зменшенні випадків клостридіальної інфекції в лікарні.

Ключові слова: клостридіальна інфекція, безпека пацієнтів, ізоляція пацієнта, профілактичні заходи, роль медсестер в профілактиці.

По результатам анализа научной литературы установлено, что клостридиальные инфекции (CDI) в настоящее время являются серьезной проблемой здравоохранения во всем мире из-за растущей заболеваемости и смертности, и в то же время они становятся самой распространенной причиной возникновения диарейных заболеваний у госпитализированных пациентов. По мере роста заболеваемости увеличиваются финансовые затраты на здравоохранение.

В этой работе мы анализируем профилактические меры, которые включают изоляцию контактов, гигиену рук и организацию/координацию сестринского ухода и отделений. Профилактические меры занимают много времени и значительно увеличивают рабочую нагрузку, что может повлиять на восприятие медсестрами безопасности пациентов и их способность концентрировать свои усилия на соблюдении правильных рекоммендаций по предотвращению передачи инфекции. Мы также подчеркиваем решающую роль медсестер в повышении безопасности пациентов из-за их постоянного присутствия у постели больного. Медсестры знакомы с ежедневным клиническим состоянием пациента, поэтому они могут быть эффективно вовлечены и помочь в уменьшении случаев клостридиальных инфекций в больнице.

Ключевые слова: клостридиальные инфекции, безопасность пациентов, изоляция пациента, профилактические меры, роль медсестер в профилактике.

Конфлікт інтересів: відсутній.

Conflicts of interest: authors have no conflicts of interest to declare.

\section{Відомості про авторів}

Ivanková Viera - PhDr., St. Elizabeth University of Health and Social Sciences, Bratislava - doctoral study; Field office of bl. Metód Dominik Trčka, Michalovce, Slovakia.

vierkai@centrum.sk.

Belovičová Mária - assoc. Prof., MD. PhD, St. Elizabeth University of Health and Social Sciences, Bratislava - teacher; Field office in Michalovce a Prešov; Internal Clinic for Liver Disease Diagnosis and Treatment, Remedium s.r.o. Bardejov Spa, Slovakia. mriab9@gmail.com. 